\title{
A comparison of tests for thyroglobulin antibody
}

\author{
J. R. RAWSTRON AND C. P. FARTHING \\ From the Department of Pathology, King's College Hospital \\ and Medical School, London
}

SYNOPSIS A comparison is made of tests for thyroglobulin antibody, using gel diffusion, electroprecipitin, bentonite flocculation, tanned red cell agglutination, and latex slide agglutination techniques on sera from cases of Hashimoto's disease and other thyroid disorders. Any increase in $\gamma$ globulin was also noted from the serum electrophoretic pattern. The gel diffusion and electroprecipitin tests are shown to be comparable in their sensitivity, as are the bentonite flocculation and tanned red cell agglutination tests. The flocculation and agglutination tests were oversensitive. The latex slide test in conjunction with the electro-precipitin test is recommended for routine use in the detection of Hashimoto's disease.

The occurrence of autoantibodies in various thyroid disorders is now well known. Tests have been described for the detection of antibodies directed against different components of thyroid tissue, of which those for thyroglobulin antibody are the most frequently performed. The commonest are gel diffusion precipitin techniques (Doniach and Roitt, 1957; Goudie, Anderson, Gray, Clark, Murray, and McNicol, 1957; Roitt, Campbell, and Doniach, 1958), and the tanned red cell agglutination test (Witebsky, Rose, Terplan, Paine, and Egan, 1957; Roitt and Doniach, 1958; Owen and Smart, 1958; Mackay and Perry, 1960; Roitt and Doniach, 1960). Others which have been used are the bentonite flocculation test (Ager, Hutt, and Smith, 1959), the electro-precipitin test (Watson and Whinfrey, 1958; Watson, 1960), and the latex slide agglutination test. An increase in circulating $\gamma$ globulin in many patients with Hashimoto's disease (lymphadenoid goitre) was noted by Luxton and Cooke (1956). These five tests have been compared, and an estimation of $\gamma$ globulin made from the serum electrophoretic pattern on sera from a number of patients with various thyroid disorders.

MATERIALS AND METHODS

THYROGLOBULIN Human thyroglobulin was prepared from fresh normal post-mortem thyroids by the method of Derrien, Michel, and Roche (1948), and the final solution (approximately $5 \mathrm{mg}$. thyroglobulin/ml.) was stored frozen in $1 \mathrm{ml}$. quantities. Part of the crude thyroid extract was stored frozen separately in small

Received for publication 8 August 1961. amounts and used as 'thyroid extract' in the gel diffusion and electro-precipitin tests.

GEL DIFFUSION PRECIPITIN TEST A modified Ouchterlony system was used. Petri dishes containing glycine-buffered saline-agar were prepared. Holes were cut $0.5 \mathrm{~cm}$. in diameter, $0.5 \mathrm{~cm}$. apart, in a checker-board pattern. The sera were allowed to diffuse against thyroglobulin solution ( $5 \mathrm{mg} . / \mathrm{ml}$.) and also against thyroid extract diluted 1 in 20 with normal saline. The plates were incubated at $37^{\circ} \mathrm{C}$. and examined for precipitin lines daily for one week.

TANNED RED CELL AGGLUTINATION TEST Originally the technique of Roitt and Doniach (1958) was used, with minor modifications. Later, formolized thyroglobulinsensitized cells were kindly provided by Dr. A. J. Fulthorpe, of the Wellcome Research Laboratories, Beckenham.

BENTONITE FlOCCUlation TEST The technique of Ager et al. (1959) was followed except that the dilutions were made in small glass tubes instead of in Perspex trays.

ELECTRO-PRECIPITIN TEST Watson's method (1960) was adapted for use with agar gel electrophoresis by Wieme's technique III (1959). Thyroid extract $(2 \mu 1$. of a 1 in 20 saline dilution) was placed $1.5 \mathrm{~cm}$. from the origin, at the cathode end. After 25 minutes' electrophoresis the gels were fixed, stained, washed, and dried according to Wieme's technique. Positively reacting sera showed a line of precipitate between the $\beta$ and $\gamma$ globulin zones (Fig. 1). Any increase in $\gamma$ globulin in the electrophoretic serum pattern was also noted, by comparison with a normal control serum. 


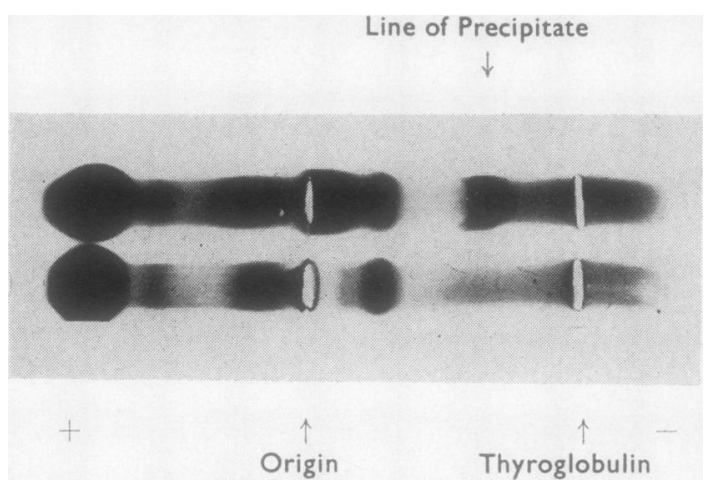

FIG. 1 Photograph of positive electro-precipitin test with a negative control below for comparison.

LATEX SLIDE TEST For this test a commercial preparation of latex particles sensitized with thyroglobulin was used. ${ }^{1}$ One drop of decomplemented patient's serum, and a separate drop of a 1 in 20 dilution of the same serum in glycine-saline buffer were placed on the slide. One drop of the latex-thyroglobulin reagent was then added to each, mixed, and rocked gently for two to three minutes. A positive reaction was shown by agglutination of the particles to form macroscopic clumps in one or both of the test dilutions, as described in the directions supplied with the kit. We found that all our positive sera reacted in the 1 in 20 dilution, but not always with the neat serum. With a negatively reacting serum the latex suspension remained milky.

\section{RESULTS}

Sera from 127 patients with various thyroid disorders (Table I) were tested. The diagnoses are those assigned on general clinical grounds. Biopsy material was examined from 14 of the 30 patients with

\section{TABLE I}

PATIENTS GROUPED ACCORDING TO THYROID DISORDER

$\begin{array}{lr}\text { Hashimoto's disease } & 30 \\ \text { Primary myxoedema } & 42 \\ \text { Thyrotoxicosis } & 12 \\ \text { Non-toxic goitre } & 29 \\ \text { Subacute thyroiditis } & 3 \\ \text { Thyroid carcinoma } & 5 \\ \text { Thyroiditis associated with: } & 2 \\ \text { Mumps } & 1 \\ \text { Myopathy } & 1 \\ \text { Diabetes } & 1 \\ \text { Dermatomyositis } & 1 \\ \text { Rheumatoid arthritis and Sjögren's disease } & 127 \\ \text { Total } & \end{array}$

${ }^{1}$ T-A TEST, manufactured by Hyland Laboratories, U.S.A., and available in Great Britain from Baxter Laboratories Ltd., High Wycombe, Bucks.
Hashimoto's disease, and the diagnosis confirmed histologically in all 14 specimens.

The results were combined for ease of tabulation A positive gel diffusion test or a positive electro운 precipitin test was recorded as a positive 'precipitir: test' for that serum. Only one serum did not give identical gel diffusion and electro-precipitin tes: results (gel diffusion negative, electro-precipitire positive from a case of non-toxic goitre). Precipitins were found by both tests in 19 of the 30 sera from patients with Hashimoto's disease. In other thyroid disorders they were detected in only two of $92 \frac{2}{2}$ cases.

The results of bentonite flocculation and tannedir red cells tests agreed to within one dilution tube of each other in all but two sera tested and have been combined under the heading of 'agglutination test' $\omega$ The exceptions were those from a case in the primary myxoedema group and a case in the associated thyroiditis group (both bentonite flocculation $1: 2,500$, and tanned red cell $1: 25$ ). Where the titres were not identical the higher dilution was taken for the purpose of this comparison. An agglutination test waš not regarded as positive unless the titre was $1: 2,500^{\circ}$ or more, as Roitt and Doniach (1958), Ager et al (1959), and Hill (1961) have shown that titres of $1: 5$ to $1: 250$ are common in patients without Hashi moto's disease. In our series 89 out of the 97 seræo from patients in groups other than Hashimoto'迟 disease had titres of at least $1: 25,34$ of at least $1: 250 \overrightarrow{\overrightarrow{0}}$ and 22 a titre of $1: 2,500$ or more. In the patients with Hashimoto's disease the agglutination titre was 1 ine 2,500 or above in 25 patients. The remaining five. had titres of 1 in 250 which were checked by repeat ing the tanned red cell test.

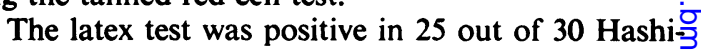
moto sera but positive in only eight out of the $9 \%$ sera from patients in other groups.

The results of the precipitin, agglutination, and latex tests are shown in Table II. The number of sera which showed an obvious increase in $\gamma$ globulif content is also included. Of the 30 patients with Hashimoto's disease, 11 showed this increase but ifs was seen in only seven of the other 97 sera.

In the gel diffusion test there was no difference either in number or in time of appearance, in pre $-\omega$ cipitate lines given by the purified thyroglobulin ase antigen and the diluted crude thyroid extract. Aff precipitate lines had appeared by the third day of incubation. In two of the cases of primary myxo edema the electro-precipitin test also detected क5 dysproteinaemic band lying within the broad $x \overline{0}$ globulin zone.

The latex slide test was positive in all cases where a precipitin test was positive, and also in 12 cases which had a negative precipitin test. In 19 of the 127 
TABLE II

RESULTS OF TESTS FOR THYROGLOBULIN ANTIBODY

Precipitin test

Agglutination test

Latex slide test

Hashimoto's disease

Primary myxoedema

Thyrotoxicosis

Non-toxic goitre

Subacute thyroiditis

Thyroid carcinoma
Assd. thyroiditis

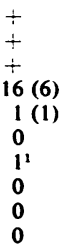

'These four cases were confirmed histologically

'Six weeks after mumps.

Figures in brackets refer to the number of sera showing an obvious increase in $\gamma$ globulin. sera the latex slide test was negative, with agglutination tests positive. On the other hand, only four of these 19 sera were from patients with Hashimoto's disease, which suggests that the latex slide test is more useful to the clinician than agglutination tests in the diagnosis of Hashimoto's disease.

\section{DISCUSSION}

It is now accepted that Hashimoto's disease is an example of an auto-immune process, and the demonstration of antibodies to thyroid components is helpful in establishing the diagnosis. The antibodies commonly tested for in routine laboratories are those directed against thyroglobulin. However, as previously stated, these antibodies can be found, although usually to a lower titre, in patients with a number of other thyroid disorders, and indeed in patients without thyroid disease (Hackett, Beech, and Forbes, 1960; Hill, 1961). A useful diagnostic test for Hashimoto's disease should therefore not be too sensitive.

The gel diffusion test is simple and does not require inactivation of the serum, but the results take longer to read than those of the other tests. The electro-precipitin test gives results in a short time and also provides a useful electrophoretic pattern of the serum proteins; an increase in $\gamma$ globulin was noted in 11 of the 30 patients with Hashimoto's disease.

The 'agglutination test' and the latex slide test were each positive in 25 of the 30 patients with Hashimoto's disease, although the composition of the two groups was not identical. The 'agglutination test' was positive in 22 of the patients with other thyroid disorders, tut the latex slide test was only positive in eight. The bentonite flocculation and tanned red cell agglutination tests are more timeconsuming to set up than the other tests. The latex slide test is simple to perform, and apart from the time taken to decomplement the serum, the results are ready within minutes.

The greater sensitivity of the agglutination tests makes them of little use for the diagnosis of Hashimoto's disease, and further experience is needed before the significance of weak titres becomes apparent. More useful information is obtained from the latex slide agglutination test and the electroprecipitin test. The latter is preferred to the gel diffusion test as it also gives an electrophoretic pattern of the serum proteins. Of the tests for thyroglobulin antibody we therefore recommend these two as the most helpful to the clinician in diagnosing Hashimoto's disease.

We are indebted to Professor A. C. Cunliffe for his constant encouragement and advice, to the clinicians of King's College Hospital who allowed us access to their patients, and to Mr. W. S. Rivers, F.I.M.L.T., for the photograph.

\section{REFERENCES}

Ager, J. A. M., Hutt, M. S. R., and Smith, G. (1959). Nature (Lond.), 184,478

Derrien, Y., Michel, R., and Roshe, J. (1948). Biochim. biophys. Acta, 2, 454.

Doniach, D., and Roitt, I. M. (1957). J. clin. Endocr., 17, 1293.

Goudie, R. B., Anderson, J. R., Gray, K. G., Clark, D. H., Murray, I. P. C., and McNicol, G. P. (1957). Lancet, 2, 976.

Hackett, E., Beech, M., and Forbes, I. J. (1960). Ibid., 2, 402.

Hill, O. W. (1961). Brit. med. J., 1, 1793.

Luxton, R. W., and Cooke, R. T. (1956). Lancet, 2, 105.

Mackay, I. R., and Perry, B. T. (1960). Aust. Ann. Med., 9, 84.

Owen, S. G., and Smart, G. A. (1958). Lancet, 2, 1034.

Roitt, I. M., Campbell, P. N., and Doniach, D. (1958). Biochem. J., 69, 248.

-

- - - (1960). Brit. med. Bull., 16, 152.

Watson, D. (1960). Aust. Ann. Med., 9, 99.

- , and Whinfrey, H. (1958). Lancet, 2, 1375

Wieme, R. J. (1959). Studies on Agar Gel Electrophoresis, p. $87 \mathrm{ff}$. Brussels.

Witebsky, E., Rose, N. R., Terplan, K., Paine, J. R., and Egan, R. W. (1957). J. Amer. med. Ass., 164, 1439. 